\title{
Study on analysis method of regional water consumption standard index
}

\author{
Li Qi-feng ${ }^{1}$, Ke Lian-feng ${ }^{2}$, Gao Hai-feng ${ }^{1}$, Qi He-shuai ${ }^{1}$ \\ ${ }^{1}$ Zhejiang Institute of Hydraulics \& Estuary(Zhejiang Institute of Marine Planning and Design), Hangzhou 310020, China; \\ ${ }^{2}$ Bureau of Agriculture, Rural Areas and Water Conservancy of Wenling City, Wenling 317500, China.
}

\begin{abstract}
According to the requirement of the regional water resources demonstration system to clarify the total water consumption control index and water consumption standard, this paper studies and proposes the establishment of water consumption standard index, puts forward the analysis principle and method of water consumption standard index based on the combination of standard reference and typical investigation, and carries out the application research with Haining Economic Development Zone as an example, The research results provide technical support for regional implementation of water resources demonstration system and enterprise water saving evaluation.
\end{abstract}

\section{Research background}

China's water resources demonstration system has been implemented for nearly 20 years. At present, the water resources demonstration system for construction projects has become a basic water resources management system to implement the regulations on the administration of water intake permit and water resources fee collection, which plays an important role in strengthening water resources management, promoting water saving and emission reduction, and building a resource-saving and environment-friendly society. In order to simplify the water resources demonstration of construction projects and realize the reform of "running once at most" in water intake management, Zhejiang province put forward the system reform of "regional water resources demonstration + water consumption standard" for the first time[1-2]. The preparation of regional water resources demonstration report is an important work to implement the regional water resources demonstration system. Its main contents include investigation of regional water resources and development and utilization status, analysis of regional total water consumption control index, demonstration of regional water intake source, analysis of regional water consumption standard, analysis of regional water intake and withdrawal impact and mitigation measures, etc., of which the key point is to determine regional water consumption standard index[3-5].

However, the current "guidelines for water resources demonstration of construction projects" and other relevant norms do not specify the analysis and calculation method of regional water consumption indicators due to their limitations. Therefore, it is of great significance to carry out the research on regional total water consumption control index and regional water consumption standard analysis method to determine water consumption standard index.

\section{System selection of water consumption standard index}

Regional water consumption standard is an important link in the implementation of water quota management system and water efficiency control red line, and it is also the key link of regional water resources demonstration + water consumption standard system, and the selection of appropriate indicators is the core of the key role of water consumption standard. Considering the demand difference of construction projects before and after entering the park, the use of water consumption standard mainly includes two aspects: whether the construction project is suitable for access and scientific evaluation of water-saving level of existing construction projects. Therefore, the regional water consumption standard index can be divided into two forms according to the use: one is the project access water consumption standard index, which is suitable for the evaluation of the water saving level of a new single project and an important reference for judging whether the project is reexamined into the region; The second is the standard index of water consumption for project evaluation, which is applicable to the evaluation of water-saving level of existing single project and an important reference for judging whether the project meets the regional watersaving requirements. It is an important basis for strengthening the water-saving management of regional projects.

In order to further promote the efficient utilization of water resources, the water consumption index reflecting the industrial water level and water use value is selected

\footnotetext{
${ }^{*}$ Corresponding author: 396372919@qq.com
} 
as the regional water consumption index. The water consumption per unit added value and water consumption per unit product are selected. The water consumption per unit product can better reflect the water consumption level of a single product, but as a regional water consumption index, it is relatively limited by the product type, and it is difficult to represent the regional water-saving level; although the water consumption per unit added value is difficult to investigate and analyse, it basically has the water consumption index conditions to guide the watersaving level of the project. For the existing water consumption index, the unit of water consumption should be selected as the standard of water consumption.

\section{Analysis principle and method of water consumption standard index}

\subsection{Analysis Principle of Water Consumption Standard Index}

The water consumption standard is loose, the short-term development is satisfied, and the medium and long-term development potential will be restricted; The tight water consumption standard is equivalent to increasing the access conditions and restricting the entry of some industries or projects, but it can leave more space for medium and long-term development. Reasonable determination of regional water consumption standard is of great significance to guide the development of regional industry. In addition, when determining the standard of water consumption, we should also analyze the factors such as regional allowable water quantity, water resource endowment conditions, regional total water consumption and water use efficiency indicators. The above indicators have a large space to adjust, so they can be appropriately lenient, and vice versa.

According to the requirements of regional economic and social development and the water efficiency control requirements of the upper administrative region, combined with the investigation of current enterprises, in order to promote the current enterprises to save water and guide the admittance of potential or new industry enterprises, the regional water consumption standard index principles are proposed as follows.

(1) The principle of ensuring applicability. Based on the actual situation of the region, ensure the applicability of the proposed water consumption standard indicators in the region, truly realize the role of guiding the relevant enterprises in the region to save water, and play a control role in the approval of water intake permit management of potential enterprises of the same type.

(2) the principle of advanced nature. The advanced nature of water resources with high efficiency and high value utilization should be embodied. Based on the application of the current situation, combined with the current situation of relevant enterprise statistical analysis and water balance test, the regional water consumption standard index should be defined according to the advanced level of water consumption and water consumption.
(3) In line with the principle of regional development and control. It should be in line with the requirements of regional development and water use control, especially for the planning of new industrial enterprises, it is required to meet the industrial economic growth goals proposed in the regional development plan, as well as the control constraints of the total amount of water use and water use efficiency of regional water resources.

(4) "Double control" principle. The determination of regional water consumption standard index should be coordinated with the "double control" index of regional water consumption (i.e. total water consumption index and water use efficiency index), and strictly restricted by the water consumption index of the upper administrative region.

\subsection{Analysis Method of Water Consumption Standard Index}

The analysis of water consumption standard index is determined by the combination of standard quotation and typical investigation, in which the water consumption index of unit product mainly adopts the standard quotation, and the water consumption index of unit added value mainly adopts the investigation method of typical enterprises.

(1) Analysis of water consumption per unit product

According to the product water intake quota value determined by relevant standards, the advanced value of water intake quota index specified in the specification and standard is taken as the unit product water consumption, which is used to guide the access of new projects; the general value of water intake quota index specified in the specification and standard is taken as the water consumption of unit product, which is used to guide the evaluation of water-saving level of existing projects.

(2) Analysis of water consumption per unit added value

According to the relevant investigation and analysis results, according to the method of water consumption standard, and considering the actual water consumption level of the region, the regional leading industries and other industries are divided. Based on the industrial sectors specified in the national economic industry classification, according to the leading industries and other industries, for different types of industries, based on the water consumption of the existing representative enterprises in the survey area, the average value is taken as the project access water consumption standard, and the more advanced value is taken as the project evaluation water consumption standard.

$$
\begin{gathered}
I_{z}=\stackrel{\stackrel{\circ}{\mathrm{a}} I_{i=1} / N}{I_{p}=a ? I_{z}}
\end{gathered}
$$

Formula: 
$I_{z}, I_{p}$ Water consumption standard index of a certain industry project, Water consumption standard index of regional project evaluation in a certain industry.

$I_{i}$ -Water consumption per unit added value of typical enterprise $\mathrm{i}$ in an industry, $\mathrm{i}=1,2,3, \ldots, \mathrm{N}, \mathrm{N}$ represents the number of typical enterprises.

$a$ - The ratio between the advanced value and the average value of water consumption standard. The value is between 0 and 1 , which is determined according to the control requirements of regional water-saving level.

\subsection{Main steps of determining water consumption standard index}

According to the analysis method of water consumption standard index, based on the standard reference and typical investigation, the specific steps of analysis and determination of regional water consumption standard index with water consumption per unit added value as index are proposed.

(1) Systematically investigate the current situation of water consumption indicators such as water consumption per unit product and water consumption per unit added value of industrial enterprises in regional leading industries or major water consumption industries, and find out the water efficiency level of industrial enterprises in different industries.

(2) combined with the results of the survey of water efficiency in different regions of the country, we obtained the technical guidelines, comprehensively evaluated the progressiveness of water consumption indicators of different industries in different regions, and sorted the water consumption index according to the advanced level of water efficiency.

(3) If the water consumption per unit product is taken as the water consumption standard, the advanced value of the water intake quota in the standard is taken as the water consumption standard of the regional leading industry project access, and the common value of the water intake quota in the standard is taken as the water consumption standard of the regional leading industry project water saving evaluation.

(4) Taking the water consumption per unit of added value as the water consumption standard, considering the advanced degree of water consumption index of regional sample enterprises and the surplus degree of regional total water consumption index, on the premise of appropriate adjustment, the average value of the top $20 \%$ advanced samples is selected as the water consumption standard of regional leading industry projects, The average value of the top $50 \%$ advanced samples is selected as the water consumption evaluation standard of regional leading industry projects.

\section{Case study}

\subsection{Survey of the Research Area}

Haining Economic Development Zone, located in Haining City, Zhejiang Province, is a national transformation and upgrading demonstration development zone of the Yangtze River economic belt, with a total area of 54.2 square kilometers. It has formed four leading industries: fashion industry, equipment manufacturing and electronic information, food and biological medicine, and new energy and new materials. The water supply of the park is centralized by Haining No.3 water plant, and the selfcontained water takes the river network as the water source. The total water consumption of the park is 29.75 million $\mathrm{m}^{3}$.

\subsection{Investigation on water use efficiency index of typical enterprises}

The research focuses on 142 related enterprises, including five leading industries: textile industry, textile and garment manufacturing industry, leather products and footwear industry, rubber and plastic products industry, electrical machinery and equipment manufacturing industry. According to the survey results of water consumption of value-added of typical enterprises in Haining Economic Development Zone, the average level, more advanced level and advanced level of water consumption of value-added of leading industries can be obtained through summary analysis. The survey statistics of water use efficiency of typical enterprises in the study area are shown in Table 1.

Table 1. Investigation and statistics of water use efficiency of typical enterprises in the study area

\begin{tabular}{|c|c|c|c|c|}
\hline \multirow[t]{2}{*}{$\begin{array}{c}\text { Order } \\
\text { numb } \\
\text { er }\end{array}$} & \multirow[t]{2}{*}{ Industry type } & \multirow{2}{*}{$\begin{array}{l}\text { Numbe } \\
\text { r of } \\
\text { typical } \\
\text { enterpri } \\
\text { ses }\end{array}$} & \multicolumn{2}{|c|}{$\begin{array}{c}\text { Water consumption } \\
\text { per unit added value } \\
\left(\mathrm{m}^{3} / 10000\right. \\
\text { yuan })\end{array}$} \\
\hline & & & $\begin{array}{l}\text { Averag } \\
\text { e level }\end{array}$ & $\begin{array}{c}\text { Advance } \\
\text { d level }\end{array}$ \\
\hline 1 & Textile industry & 29 & 14.5 & 2.5 \\
\hline 2 & $\begin{array}{c}\text { Textile and } \\
\text { Apparel } \\
\text { Manufacturing }\end{array}$ & 24 & 11.5 & 3.5 \\
\hline 3 & $\begin{array}{l}\text { Leather } \\
\text { products and } \\
\text { footwear }\end{array}$ & 28 & 9.0 & 4.5 \\
\hline 4 & $\begin{array}{c}\text { Rubber and } \\
\text { plastic products } \\
\text { industry } \\
\end{array}$ & 14 & 3.8 & 2.5 \\
\hline 5 & $\begin{array}{c}\text { Electrical } \\
\text { machinery and } \\
\text { equipment } \\
\text { manufacturing } \\
\text { industry }\end{array}$ & 10 & 4.5 & 2.0 \\
\hline 6 & Other industries & 32 & 12.0 & 5.5 \\
\hline
\end{tabular}




\subsection{Determination of regional water consumption standard index}

\subsubsection{Standard index of water consumption for project access}

According to the determined leading industries and other industries, for the industry types specified in the specification, the standard index of water consumption is the water consumption per unit product, and the standard index of water consumption for project access is the general value of water intake quota determined in Zhejiang water consumption (intake) quota (2019). For the industry type not specified in the specification, the standard index of water consumption is water consumption per unit value added, which is the average value of water use efficiency of typical enterprises.

\subsubsection{Standard index of water consumption for project evaluation}

According to the determined leading industries and other industries, for the industry types specified in the specification, the water consumption standard index selects the water consumption per unit product, and the value of water consumption standard index for project evaluation is the advanced value of water intake quota determined in Zhejiang water consumption (intake) quota (2019). For the industry type not specified in the specification, the standard index of water consumption is water consumption per unit value added, which is the advanced level value of water use efficiency of typical enterprises.

The standard values of water consumption for different industries are shown in Table 2.

Table 2. Results of water consumption standard index (water consumption per unit added value) in the study area

\begin{tabular}{|c|c|c|c|}
\hline $\begin{array}{c}\text { Order } \\
\text { number }\end{array}$ & Industry type & $I_{z}$ & $I_{p}$ \\
\hline 1 & Textile industry & 14.5 & 2.5 \\
\hline 2 & $\begin{array}{c}\text { Textile and Apparel } \\
\text { Manufacturing }\end{array}$ & 11.5 & 3.5 \\
\hline 3 & $\begin{array}{c}\text { Leather products and } \\
\text { footwear }\end{array}$ & 9.0 & 4.5 \\
\hline 4 & $\begin{array}{c}\text { Rubber and plastic } \\
\text { products industry }\end{array}$ & 3.8 & 2.5 \\
\hline 5 & $\begin{array}{c}\text { Electrical machinery } \\
\text { and equipment } \\
\text { manufacturing } \\
\text { industry }\end{array}$ & 4.5 & 2.0 \\
\hline 6 & Other industries & 12.0 & 5.5 \\
\hline
\end{tabular}

In the specific practical application, for specific construction projects or water users, first of all, we should make clear whether there is water intake quota for the leading products of the project or water users according to the water intake quota specification. Secondly, if the water quota of the project or unit product is specified in the specification, the standard index of water consumption per unit product is selected; otherwise, the standard index of water consumption per unit added value is selected.

\section{Conclusion}

In view of the lack of calculation methods for important indicators related to regional water resources demonstration in the existing guidelines for water resources demonstration of construction projects and other relevant specifications, this study proposes to take water consumption per unit product and water consumption per unit added value as standard indicators, The principle and method of water consumption standard index analysis based on the combination of normative standard reference and typical investigation for project access and project evaluation are proposed, and the results are applied to the demonstration of regional water resources in Haining Economic Development Zone. The research results provide a reference analysis method for the determination of important indicators in the preparation of regional water resources demonstration report, and provide technical support for the implementation of regional water resources demonstration system.

\section{Acknowledgments}

National Key R\&D Program of China (2019YFC0408804)

\section{Reference}

1. Chen Hong-wei, Practices of Water Resources Appraisal of Construction Project[J]. China Water Resources, 2005,(11):16-18.

2. Department of Water Resources of Zhejiang Province. Notice on carrying out pilot work of regional water resources demonstration + water consumption standard management[Z]. Zhejiang Province: Department of Water Resources of Zhejiang Province, 2018.

3. Wang Shi-wu, Li Qi-feng, Qi He-shuai. Exploration and Practice of Regional Water Resources Assessment and Water Consumption Standard System[J]. 2019,(5):29-33.

4. Han Na, Harmony theory based decomposition method of total water consumption index in Zhengzhou[J].Henan Water Resources \& South-toNorth Water Diversion, 2020,(5):80-82.

5. Guan Xi-ke, Yang Dan, Zhang Hao. Research on Water Consumption and Efficiency of Management Performance Evaluation Based on the Entropy Method[J]. China Rural Water and Hydropower, 2013,(7):92-95. 